\title{
Mathematical Communication Characteristics of Pre-Service Primary School Teacher in Explaining the Area of Trapezoid Reviewed from School Origin
}

\author{
Zainal Abidin \\ STKIP Al Hikmah Surabaya \\ Corresponding author: nidiba@gmail.com
}

\begin{abstract}
This study aims to know the characteristics of mathematical communication of pre-service primary school teachers. The material used as the object of research is geometry. It requires the ability of algebra and spatial skills. The area of trapezoid is selected as the topic since it is perceived as the most complex of all plane shapes studied in primary school. It is because the calculation of the area of trapezoid entails three variables. The ability of mathematical communication involves the ability to write and explain. This ability is examined based on the background of students' secondary school. The subjects of this study were 15 students of Primary Teacher Education, STKIP Al Hikmah Surabaya in academic year 2017-2018. The types of mathematical communication are grouped according to their characteristics. Written communication is sharpened by oral communication. The results were analyzed to investigate the relevance of such abilities with the subjects' background of their secondary school (SMA, SMK, or MA). The results indicate that the characteristics of written communication consist of: (1) narrative, (2) procedure, and (3) dialogue. Meanwbile, the characteristics of oral communication consist of: (1) lecture, (2) instructional, and (3) discussion. Pre-service teachers graduated from SMA bave better mathematical communication skills than those from $S M K$ and $M A$.
\end{abstract}

Keywords: Pre-service primary school teacher, mathematical communication, the area of trapezoid.

\section{Introduction}

Communication is the most important activity of human life. Every human being always needs communication. According to Rogers \& O. Lawrence Kincaid, with the existence of human communication can form or do exchange of information with each other which will eventually come to each other understanding (Cangara, 2004: 19). One of the important elements in the learning process is communication. For pre-service teachers, communication determines their success in transferring knowledge. In this term, communication includes written communication and oral communication. However, they are frequently linearly related. A person who has good written communication skills is likely to have good oral communication and vice versa. Ideally, these two types of communication are aligned. Written and oral communications are absolutely necessary for pre-service teacher.

In mathematics, communication can be used to share ideas and build an understanding of a concept (Hirschfeld-Cotton in Fitriyah Habsah, 2017). 
Communication skills in mathematics learning is one of the abilities that need to be developed (Untayana, JR \& Harta, I., 2016). Because of the importance of mathematical communication skills, a prospective educator must understand mathematical communication and know the aspects or indicators of mathematical communication, so that the implementation of mathematics learning needs to be designed as well as possible so that the goal of developing mathematical communication skills can be achieved (Hodiyanto, 2017).

Written communication describes the demands of someone's thinking in expressing the ideas. The more structured the expression, the better the receivers capture the idea. It also affects the receiver's absorption. Writing communication skills can be interpreted as a person's ability to translate and organize the knowledge they have gained into a written sentence arrangement that can make it easier for readers to understand what is meant (Ardina \& Sa'dijah, 2016). Such skills include trainable skill (ability). Pre-service teachers should practice their writing skills intensively to make their ideas acceptable.

In association with their task of educator, pre-service teachers are required to have good oral communication. Such ability reflects the depth of a person's knowledge. Moreover, teachers with good oral communication will convey the materials easily to be accepted and absorbed by students. The failure in oral communication also leads to the failure in learning process.

Baroody (1993) declared the role of communication in learning mathematics entails mathematics learning as language and mathematics learning as social activity. As a language, the role of communication in learning mathematics is to convey ideas and concepts of mathematics precisely and clearly. Furthermore, mathematics learning is expected to facilitate learners in communicating ideas or mathematical reasons through several aspects, namely representing (describing/showing), listening discussing (exchanging opinion), reading, and writing.

STKIP Al Hikmah as a campus that focuses on printing teachers who have acceptable communication skills to students. Therefore this research is needed to find out the communication characteristics of prospective teacher students from various diverse secondary schools. Especially for students of primary school teacher candidates, communication is more specific because it deals with students whose mind sets are still simple.

The pre-service teacher students in this study are undergraduate students who take an elementary school teacher education study program. According to KBBI, students are people who study in college. Meanwhile, according to Sarwono, students are each person who is registered to take part in a college at the age limit of around 18-30 years. Students are a group in a society that gets its status, because of the bond with a college

Mathematical communication is the ability to express mathematical ideas coherently to peers, teachers or others through spoken and written language (Armiati, 2009: p. 271). It implies that mathematical communication is an important skill in learning mathematics. One of the ways to express the ability of mathematical communication is with relevant representation. Representation is a new form of a result of translation of a problem or interpretation of diagram or physical model into symbols or words (NCTM, 1989). Some examples of mathematical representation as adduced by Cai, Lane and Jakabcsin (1996) are visuals (i.e., drawings, graphs and tables) and algebra (mathematical expression), as well as writing in the language itself (both formal and informal written texts).

Lacoe in Rofiudin (2017) suggested mathematical communication consists of four components of: (1) reflecting and clarifying thoughts about mathematical ideas, (2) connecting everyday language with mathematic languages using symbols, (3) using the 
skills of reading, listening, interpreting, and evaluating mathematical ideas, and (4) using mathematical ideas to guess and make convincing arguments.

Furthermore, Agustyaningrum (2011) propounded the aspects of mathematical communication, namely: (1) the ability to express mathematical ideas through oral, written and visual description, (2) the ability to interpret and evaluate mathematical ideas, both orally and in writing, and 3) the ability to use terms, mathematical symbols, and structures to model situations or problems of mathematics.

According to Fatimah (2012), verbal mathematical communication can be interpreted in writing or oral. Understanding mathematical concepts can be measured from the process of communicating ideas or mathematical reasons (Aini, Sukestiyarno, \& Waluya, 2015). Thus, written and oral mathematical reason is part of the mathematical communication that must exist in mathematics learning. It is intended to develop logic and to measure an understanding of mathematical concepts.

The present study aimed to reveal the characteristics of mathematical communication of pre-service primary school teachers based on their school origin. It is assumed to be important since primary school teachers are those who embed the basic concepts that will be used on an ongoing basis. The learning experience from previous educational institutions also affects their mathematical communication. Material used as the object of this research is geometry. It also involves algebraic capabilities and simple spatial skills. Specifically, the area of trapezoid was chosen because it is perceived as the most complex of all plane shapes studied in primary school.

Table 1. Number of variables on shapes

\begin{tabular}{lllll}
\hline No & Shape & Formula & Variable(s) & $\begin{array}{l}\text { Number of } \\
\text { variable(s) }\end{array}$ \\
\hline $\mathbf{1}$ & Square & $\mathrm{s}^{2}$ & $\mathrm{~s}$ & 1 \\
\hline $\mathbf{2}$ & Rectangle & $\mathrm{p} \mathrm{x}$ & $\mathrm{p}, \mathrm{l}$ & 2 \\
\hline $\mathbf{3}$ & Triangle & $1 / 2 \times \mathrm{axt}$ & $\mathrm{a}, \mathrm{t}$ & 2 \\
\hline $\mathbf{4}$ & Parallelogram & $\mathrm{a} \times \mathrm{t}$ & $\mathrm{a}, \mathrm{t}$ & 2 \\
\hline $\mathbf{5}$ & Rhombus & $1 / 2 \times \mathrm{d}_{1} \times \mathrm{d}_{2}$ & $\mathrm{~d}_{1}, \mathrm{~d}_{2}$ & 2 \\
\hline $\mathbf{6}$ & Kite & $1 / 2 \times \mathrm{d}_{1} \times \mathrm{d}_{2}$ & $\mathrm{~d}_{1}, \mathrm{~d}_{2}$ & 2 \\
\hline $\mathbf{7}$ & Trapezoid & $1 / 2 \times(\mathrm{a}+\mathrm{b}) \times \mathrm{t}$ & $\mathrm{a}, \mathrm{b}, \mathrm{t}$ & 3 \\
\hline $\mathbf{8}$ & Circle & $\pi \times \mathrm{r}^{2}$ & $\mathrm{r}$ & 1 \\
\hline
\end{tabular}

In general, there are three types of trapezoid, namely right trapezoid, isosceles trapezoid, and just trapezoid. Among other shapes, trapezoid is the most complex flat shape. To determine the area of a trapezoid, there are three variables that must be identified. Hence, trapezoid is suitable for measuring the conceptual understanding of pre-service primary school teachers. Table 1 shows the variables of various plane shapes.

Trapezoid is a convex quadrilateral with at least one pair of parallel sides. The parallel sides are called the basis of the trapezoid and the other two sides are called the legs or the lateral sides (http://en.wikipedia.org). In general, there are three types of trapezoid, namely (1) right trapezoid, (2) isosceles trapezoid, and (3) obtuse trapezoid.

\section{Research Methods}

The present study is a qualitative research as implied by the characteristics of qualitative research proposed by Fraengkel and Wallen (2009). These characteristics are: (1) natural, it is done in accordance with the actual situation and the researcher as the main instrument, (2) the data is descriptive, in the form of a series of words or images, 
(3) more emphasis on process than result, (4) data processing done inductively, and (5) it is aimed at all activities undertaken by individuals.

The subjects of the present study were all students of Primary Teacher Education (PGSD), STKIP Al Hikmah Surabaya academic year 2017-2018 (15 students). The freshmen were selected as the research subject because they had the shortest span of time, namely between high secondary school and higher education. Thus, it is relevant to the purpose of research, namely to reveal the characteristics of mathematical communication of pre-service primary school teacher reviewed from their origin of secondary school. School data is obtained from campus data in the academic section. The following table shows the subject distribution based on the origin of the secondary school.

Table 2. The school origin of the subjects

\begin{tabular}{clc}
\hline No & The school origin & Number of subjects \\
\hline $\mathbf{1}$ & SMA/SMU & 6 \\
\hline $\mathbf{2}$ & $\begin{array}{l}\text { SMK/Vocational } \\
\text { school }\end{array}$ & 4 \\
\hline $\mathbf{3}$ & MA/Madrasah Aliyah & 5 \\
\hline & Total & 15 \\
\hline
\end{tabular}

The research data was obtained by collecting written test results, interview results and microteaching results. In analysing written communication data, the results of writing test work on research subjects are grouped according to the style of presentation. Whereas to analyse oral communication data is done by scoring each subject based on the microteaching scoring guidelines

The characteristics of written communication are derived from the data of mathematical ability generated from the results of the written test. This test contained geometry, specifically the area of trapezoid. The question posed in the test was: "How do you explain the area of a trapezoid to the students." The subjects could write the answers without any limitation. It is intended that the subjects could write based on their own styles. It is assumed that the way the subject writes down the answers is the best-believed way to explain the area of a trapezoid.

To sharpen the information, written answers are clarified through interviews and micro-teaching. Interviews were done individually to explore to what extent the subject understand the material. At microteaching, subjects had the opportunity to explain the material in front of the peers who acted as elementary students. The writing ability is equated with oral skills. Furthermore, the results of mathematical communication were compared with the background of the secondary school origin.

\section{Results and Discussion}

The results showed that 15 subjects of written communication were diverse. The results showed the variety in presenting ideas or concepts to explain the area of trapezoid. In general, there are three types, namely: (1) narration, (2) procedures, and (3) dialogue. The distribution of the types of written communication proposed by research subjects is demonstrated in Table 3.

Table 3 shows that the form of written communication mostly used by the subject is narration. Aside from the six subjects who preferred narrative form, two subjects wrote short narratives while four subjects wrote longer narratives. Subjects who wrote longer narratives used their images to explain their ideas. They used the image to help students in understanding the material. Meanwhile, subjects who wrote short narratives did not use images in conveying the material. Compared with the results of oral 
communication, this type of pre-service teachers has a propensity to like lecturing method in the learning process

Table 3. Forms of written communication

\begin{tabular}{|c|c|c|}
\hline No & $\begin{array}{l}\text { Form } \\
\text { Narration }\end{array}$ & Number of subjects \\
\hline 1 & Narrative & 6 \\
\hline 2 & Procedure & 5 \\
\hline 3 & Dialogue & 3 \\
\hline 4 & Other & 1 \\
\hline \multicolumn{2}{|c|}{ Total } & 15 \\
\hline
\end{tabular}

The procedure form was used by five subjects in explaining the area of trapezoid presented step by step. This form is more structured. The explanations given step by step make it easy to understand ideas or concepts. From the five subjects, none used images in explaining the area of trapezoid. Compared with the results of oral communication, this type of pre-service teachers has a propensity to like the style of instruction in the learning process.

The dialog form was selected by three subjects. In explaining the area of trapezoid, these pre-service primary school teachers used a virtual dialogue between teacher and students in the class. The language used in the oral and written communication was similar. The dialogue is the imagination of the subject. Generally, at the end of the dialogue, the students will understand the teacher's explanation. Compared with the results of oral communication, it shows that this type of pre-service teachers has a propensity to prefer the style of discussion in the learning process.

There was one subject who did not write any ideas or concepts in explaining the area of trapezoid. The possibility is that the subject does not know what to write. The subject might not understand the question or have no knowledge about trapezoid. When the subject was posed with the question whether the subject ever hear, read or learn about trapezoid, the answer was 'yes but the subject could not recall it. Further investigation indicated that the subject was confused between trapezoid and parallelogram.

The following data shows the relationship between the type of written communication used by the subjects and the school origin. There is no clear pattern between the type of subject's written communication and the school origin. None of subjects graduated from SMK/vocational school used the type of procedure. Generally, they obtain a lot of practical activities and internships that use a lot of steps (procedures) in completing the task. Meanwhile, subjects graduated from MA are not used with internship, hence they tend to use the type of procedure.

Table 4. Type of written communication based on school origin

\begin{tabular}{lccc}
\hline \multirow{2}{*}{$\begin{array}{l}\text { Type of written } \\
\text { communication }\end{array}$} & \multicolumn{3}{c}{ The origin of the school } \\
\cline { 2 - 4 } & SMA & SMK & MA \\
\hline Narrative & 4 & 2 & 0 \\
\hline Procedure & 1 & 0 & 2 \\
\hline Dialogue & 1 & 3 & 1 \\
\hline
\end{tabular}

The type of written communication used in explaining the area of trapezoid shows the extent of understanding of pre-service teachers. In proposing an answer, none presented an explicit formula and provided a simple example of relevant question. Some 
subjects neither write the formula nor give examples of problems and solutions. From the results of the written test, it is known that some subjects presented right and some presented wrong formula. Table 5 shows the data of the writing ability of subjects in explaining the area of trapezoid in relation with their school origin. The writing ability was assessed based on the accuracy of the concept and whether the formula is right or wrong. If the concept is correct and the formula written along with the description is also correct, the answer is valid. Furthermore, the number of valid answers proposed by the subjects is expressed in percentages.

From the results of this writing ability test, interviews were then conducted to explore more deeply. The following are examples of transcript pieces from the interview with subject 03 .

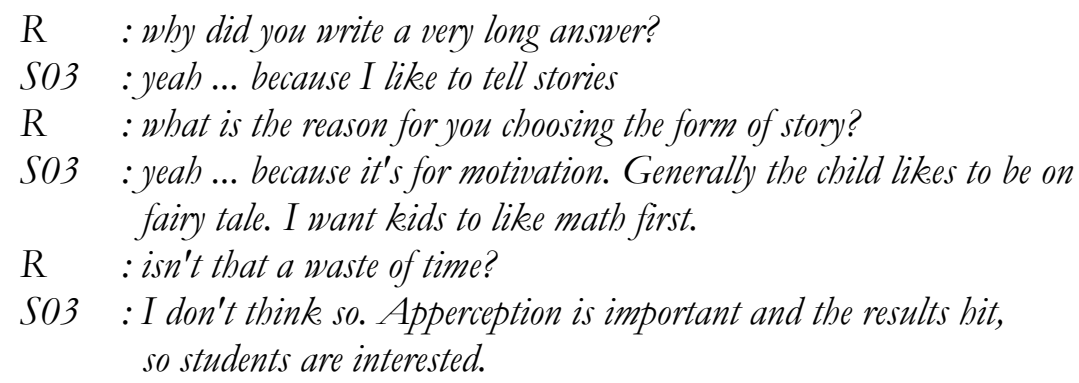

The results of the interview above show that the subject chooses to answer in narrative form because the person believes that to explain something needs to be apperception as well as to motivate students. This is different from the results of interviews with subject 07 which chose the form of dialogue in writing answers, such as the following transcript pieces.

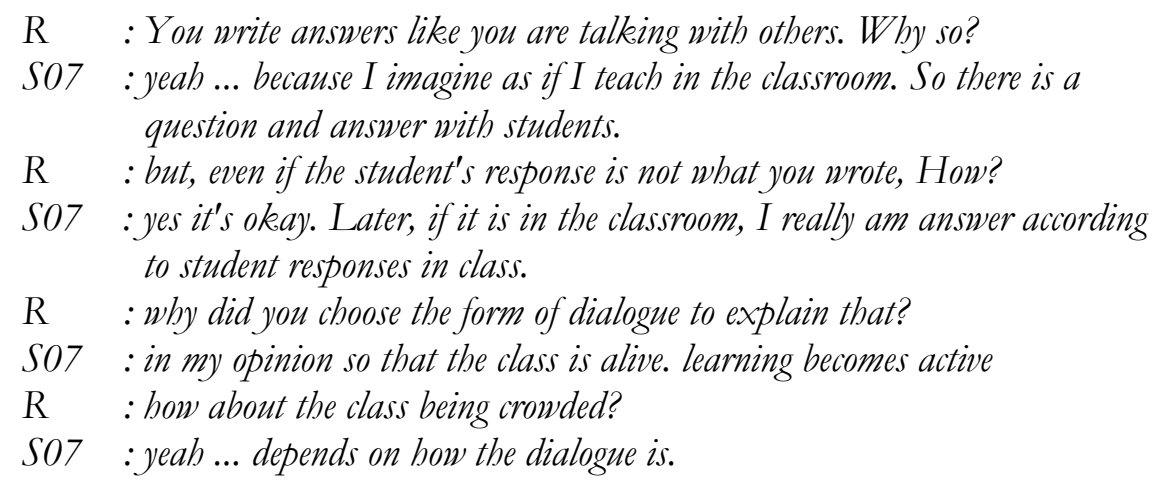

The verbal communication of subjects was assessed during the micro teaching. Out of 15 subjects, only one subject could not attend this activity. Various methods used by the subjects in explaining the area of trapezoid indicate the level of subject's understanding of the material. Each subject displayed distinguished style. Generally, the types of oral communication can be classified into three types, namely lecturing type, instructional type, and discussion type.

Table 5. The ability of written communication based on school origin

\begin{tabular}{ll}
\hline The school origin & Percentage \\
\hline SMA & 83.3 \\
\hline SMK & 25.0 \\
\hline MA & 60.0 \\
\hline
\end{tabular}


In terms of lecturing type, the subject generally explains the material with one-way communication method. There is no dialogue between teacher and students from the stage of reviewing the prerequisite material to the stage of explaining what is trapezoid, its properties and formulas, examples of problems and how to solve them. Consequently, some materials are skipped or even not conveyed. In contrast to those who have instructional type, the subjects describe the material in a structured way, step by step in detail. Hence, it is easier for receiver to accept the material. Meanwhile, the subjects with the type of discussion invite audiences to have dialogue, including by giving a question that is then responded by the audience. Not all ideas submitted by the audience are true, but all of them are accommodated. Subsequently, it is discussed until the correct result is obtained.

To assess the oral communication skills of the subjects, seven indicators were determined, namely: (1) The subject gives correct definition of trapezoid, (2) The subject can mention characteristics of trapezoid, (3) The subject can mention the types of trapezoid, (4) The subject can mention the type of trapezoid from an image, (5) The subject can provide the correct formula, (6) The subject can give example of question correctly, and (7) The subject can provide correct solution for the problem. Each indicator has different level, but the maximum total score of oral communication skills is 100.

Based on the indicators, the score of oral communication skills of the subject in explaining the area of trapezoid was obtained. Furthermore, the results were grouped based on the subjects' school origin and the average was determined. The results are shown in Table 6.

Table 6. The ability of oral communication based on school origin

\begin{tabular}{lc}
\hline The school origin & Score \\
\hline SMA & 80 \\
\hline SMK & 50 \\
\hline MA & 70 \\
\hline
\end{tabular}

From the above explanation, it appears that the written ability and oral ability of the subjects are comparable. If one's writing skill is good, the oral communication skill is also good. Conversely, if one's writing skill is less, the oral communication skill is relatively less. In addition, the results also show there is a correlation between the type of written communication and the type of oral communication. The relationship between the two skills is presented in Table 7.

Table 7. The characteristics of mathematical communication

\begin{tabular}{ccc}
\hline $\begin{array}{c}\text { Written } \\
\text { Communication }\end{array}$ & & $\begin{array}{c}\text { Oral } \\
\text { Communication }\end{array}$ \\
\hline Narrative & $\longrightarrow$ & Lecture \\
\hline Procedure & $\longrightarrow$ & Instructional \\
\hline Dialogue & $\longrightarrow$ & Discussion \\
\hline
\end{tabular}

This study can describe the relationship between written communication characteristics and oral communication characteristics. This is different from similar studies conducted by Iswita Dewi (2014) who reviewed the communication skills of pre-service teacher students based on gender. The results of the study said that male students' mathematical verbal communication skills were better (accurate) than female students. Another study conducted by Jazuli A \& Untarti R (2014) said that mathematical communication of pre- 
service teachers differed between upper group students and lower groups. This difference includes the level of readability, self-confidence, and relevance to Islamic culture

\section{Conclusion}

The characteristics of mathematical communication of pre-service primary teachers are examined based on their characteristics in written communication and oral communication. The results of this study indicate that there are three types of written communication characteristics, namely narrative, procedure, and dialogue. Based on the origin of the school, the ability of written communication of pre-service primary school teachers from SMA/SMU, SMK/vocational school, and MA is 83.3, 25, and 60, respectively. Meanwhile, the type of oral communication characteristics also consists of three types, namely lecturing, instructional, and discussion. Based on the origin of the school, the oral communication skills of pre-service primary school teachers of SMA/SMU, SMK/vocational school, and MA are 80, 50, and 70, respectively. Thus, the mathematical ability of pre-service primary school teachers is better than those from SMK/vocational school and MA.

These communication characteristics are viewed from the style of trapezoidal material delivery to students. The results show that there is a correlation between the type of written communication and the type of oral communication. Characteristics of written communication of narrative type tend to associate with oral communication by lecturing type. Meanwhile, procedure type is associated with instructional type, and dialogue type is associated with discussion type.

\section{Bibliography}

Agustyaningrum, N. (2011). Implementasi model pembelajaran learning cycle 5E untuk meningkatkan kemampuan komunikasi matematis siswa kelas IXB SMP Negeri 2 Sleman. Paper presented at Seminar Nasional Matematika and Pendidikan Matematika, 2(4). Retrieved from http://eprints.uny.ac.id/7389/1/1p-34.pdf

Aini, N., Sukestiyarno, S., \& Waluya, B.. (2015). Analisis komunikasi matematis dan tanggung jawab pada pembelajaran formulate share listen create materi segiempat. Unnes Journal of Mathematics Education Research, 4 (2).

Ardina FR \& Sa'dijah C. 2016. Analisis Lembar Kerja Siswa Dalam Meningkatkan Komunikasi Matematis Tulis Siswa, Jurnal Pendidikan; Teori, Penelitian dan pengembangan. Vol. 1 No. 2 Tahun 2016. Hal 171 -180

Armiati. (2009). Komunikasi matematis dan kecerdasan emosional. Paper presented at Seminar Nasional Matematika dan Pendidikan Matematika. Retrieved from http://eprints.uny.ac.id/7030/1/P16-Armiati.pdf

Baroody, A.J. (1993). Problem solving, reasoning, and communicating. New York: Macmillan Publishing.

Cai, J., Lane, S., \& Jakacsin, M.S. (1998). Assessing students mathematics communication. School Science and Matehmatics Journal, 96(5), 238-246.

Cangara, Hafied. 2004. Pengantar Ilmu Komunikasi. Jakarta: Kencana Prenada Media Group.

Dewi, Iswita. 2014. Profil Keakuratan Komunikasi Matematis Mahasiswa Calon Guru Ditinjau Dari perbedaan gender. Jumal Didaktik Matematika, Vol. 1 No. 2, Tahun 2014, Unsyiah NAD. 
en.wikipedia.org/wiki/Trapezoid diakses pada tanggal 6 Desember 2018 pukul 13.35 WIB.

Fatia, F. (2012). Kemampuan komunikasi matematis dan pemecahan masalah melalui problem based learning. Jurnal Penelitian dan Evaluasi Pendidikan, Vol.1.

Fraenkel \& Wallen. 2009. How to Design and Evaluate Reasearch in Education. Seventh Edition, San Francisco, the McGrow Hill Companies.

Habsah, Fitriyah. 2017. Developing Teaching Material Based on Realistic Mathematics Andoriented to the Mathematical Reasoning and Mathematical Communication. Jurnal Riset Pendidikan Matematika Vol 4 No. 1 Tahun 2017. UNY. Yogjakarta.

Hodiyanto. 2017. Kemampuan komunikasi matematis Dalam pembelajaran Matematika. Jurnal AdMathEdu, Tahun 2017 Vol. 7 No.1, UAD, Yogjakarta.

Jazuli, A \& Untarti, R. 2014. Deskripsi Percaya Diri dan Kemempuan Komunikasi Matematis Mahasiswa Calon Guru Berbasis Nilai-Bilai Budaya Islam. Prosiding Seminar LPPM UMP.

National Council of Mathematics. (1989). Curriculum and evaluation standard for school mathematics. Virginia: NCTM.

Rofiudin A. (2018). Profil Komunikasi matematis siswa dalam memecahkan masalah matematika ditinjau dari kecerdasan intelektual. Jurnal Pendidikan matematika dan Integrasinya, 1(2).

Untayana, JR \& Harta, I. 2016. Pengembangan perangkat Pembelajaran Limit Berbasis Pendekatan Saintifik berorientasi Prestasi Belajar dan Kemampuan Komunikasi Matematika. Jurnal Riset Pendidikan Matematika, Vol. 3 No. 1 tahun 2016, UNY, Yogjakarta 